\title{
Current issues of skin aging and strategies for its correction
}

Ivanishchev V.

D. F. Chebotarev State Institute of Gerontology of the National Academy of Medical Sciences of Ukraine, Kyiv, Ukraine

Corresponding author’s e-mail: meddoc@i.ua

\section{ABSTRACT}

The review analyzes current experimental and clinical data on skin aging. One of skin aging phenomena is the aging of its cells. Senescent cells produce a broad spectrum of cytokines that alter the microenvironment of tissues. The results of recent studies show that the microenvironment affects the functional activity of stem cells, which is accompanied by impairment in skin regeneration and recovery.

KEY WORDS: skin aging; skin stem cells; senescent cells; senolytics

Human aging is a destructive process that is associated to some extent with structural changes and reduced functional activity at all levels of biological organization, including the skin $[5,68,78]$. The skin has unique properties compared to other tissues, performing a number of functions: barrier, protective, immune, thermoregulatory, secretory and others. The skin is an external organ that comes into direct contact with the environment, protecting tissues and organs from mechanical damage and UV radiation [48].

Recently, a number of scientists have identified a new function of the skin - socio-psychological. Young and attractive skin has a positive effect on social behavior, reproductive status, provides a sense of confidence, promotes professional and career growth. Therefore, understanding the pathogenetic mechanisms of age-related changes in human skin, development and application of techniques and drugs, which help restore the beauty, youth and function of the skin, has become extremely important at the present stage of our society [56]. Changes in the skin are simultaneously affected by a combination of factors of endogenous (genetics, cellular metabolism, hormones and metabolic processes) and exogenous origin (chronic exposure to light, pollution, ionizing radiation, chemicals, toxins). The complex action of these factors together leads to structural and physiological transformations that occur in the epidermis, skin-epidermal junction, dermis and epidermal appendages, including hair follicles, sebaceous glands, sweat ducts and glands [7, 33, 75].

The skin is of scientific and clinical interest to experts in aesthetic and regenerative medicine, because it is the most accessible organ for both diagnosis (e.g., skin biopsy) and medical interventions, as it is convenient to apply cosmetics and pharmacotherapeutic agents locally. The most promising to date are the study of cellular mechanisms of aging associated with a decrease in the functional activity of skin stem cells (SCs) and an increase in the number of senescent cells in the dermis.

\section{NICHES OF DERMAL STEM CELLS}

The skin, like other soft tissues, is restored and renewed due to the presence of regional tissue-specific stem cells [1]. According to the literature, stem cells are located in specific sites - niches of the body. The term niche was proposed in 1978 by Schofield. A niche is understood as a microenvironment of stem cells, which provides their activity, selfrenewal and differentiation. The microenvironment itself protects stem cells and is an important factor for tissue homeostasis in the epidermis, as well as in other tissues [69]. The niche performs a trophic function, and is a signaling medium for SCs interaction [52]. Anatomical and biochemical microenvironment protects the pool of SCs from depletion, regulates the transition of cells from undifferentiated to terminally differentiated [6]. The niche consists of neighboring cells, components of the intercellular matrix (collagen, elastin), chemokines of Wnt signaling pathways, growth factors (epidermal growth factor, transforming growth factor beta, fibroblast growth factor, insulin-like growth factor), surrounding capillaries, physical parameters (hypoxia, pH) [2, $19,20,35,80]$.

Skin SCs are located in the following niches: epidermal, dermal and adipose. The epidermal stem niche consists of at least three cell populations of the SC: the bulge region of the hair follicle, sebaceous glands and the basal layer of the interfollicular epithelium [31]. Basal stem cells are transformed into transient amplifying and terminal differentiated keratinocytes. They are responsible for the physiological regeneration and repair of the epidermis during injuries caused by trauma and disease. SCs of the bulge region are differentiated into epitheliocytes of the inner and outer root sheath of the hair follicle and hair shaft cells, regulating the processes of hair folliculogenesis and hair follicle regeneration. The population of melanocytic SCs of the bulge region are responsible for the melanogenesis in dermis and hair pigmentation. SCs which differentiate into sebocytes are localized near the sebaceous glands. [19, 52, 36]. The composition of the dermal stem niche includes multipotent stem cells of the hair follicle, dermal papilla, perivascular cells located mainly near the hair follicles, which have the properties of mesenchymal stem cells. These cell populations can give rise to dermal cells, induce hair morphogenesis, participate in skin repair during traumatic injuries and diseases $[73,79,88]$. The adipose niche of the dermis is represented by adiposederived stem cells, which can be isolated from the stromal-vascular fraction of adipose tissue. They are actively involved in the mechanisms of subcutaneous adipose tissue regeneration [41]. SCs and microenvironment simultaneously form a dynamic system that determines the regenerative abilities of organisms [6] 


\section{AGE-RELATED ASPECTS OF THE SKIN STEM CELL NICHE}

$\mathrm{Ge} Y$. et al. in in vivo studies using immunofluorescence microscopy showed that in young mice the bulge region has a two-bulge structure at second telogen in contrast to the older animals, which had a single bulge. There was also a consistent tendency to the decrease in nephronectin (NPNT) regulation in hair follicle stem cells in older organisms compared to young ones. The severity of hair loss correlated with the prevalence of the phenotype with a single bulge structure. In addition, an age-related decrease in the number of hair follicle stem cells (HFSCs) was found, especially in mice with alopecia. [81].

The arrector pili muscle was separated from the wall of the hair follicle above the buldge in older hair follicles, in contrast to young hair follicles, where it attaches to the bulge's upper convexity. Arrector pili muscle attachment is mediated by NPNT expressed by stem cells [32].

On the murine skin during hair growth (anagen), the structure of a single bulge was identified, which corresponds to the potential ability of hair follicle stem cells to generate the growth of new hair. In contrast, on old hairless skin, the ability to hair grow was noticeably reduced. These observations suggest that despite the presence of HFSCs within the old bulges, they are much less able to affect the new hair growth cycle. This coincides with the study of other researchers that the effect of the old bulge on the initiation of new hair growth is reduced $[47,81]$.

A decrease in the total number of T-cells, $\mathrm{CD}^{+}$and regulatory T-cells in the skin of older mice has been proved [81]. According to Ali N. et al., in young mice, regulatory T-cells of the hair follicle promote the function of the hair follicle SCs [14]. Thus, reducing the number of regulatory T-cells of the hair follicle may affect the activity of SCs and hair growth.

In the experiment, shaving hair in the telogen phase and modelling of a wound on the skin of the mice's back led to the restoration of hair growth and pigmentation of the injured area of skin in a young mouse. In contrast, in the old mouse, no restoration of hair growth was observed even after two months of the study, and the area of skin injury remained pale because the pigmentation did not restore. The transplantation of young and old HFSCs in combination with neonatal dermal cells resulted in the formation of numerous hair follicles in the skin of nude mice. In contrast, the transplantation of young and old HFSCs in combination with old dermal cells did not result in the appearance of hair follicles in the nude mice skin in any of the cases. The obtained data convincingly support the opinion that the microenvironment of old skin is the main barrier to the full activity of hair follicle stem cells. Moreover, they demonstrate that the microenvironment of the neonatal dermis promotes the rejuvenation of old HFSCs and the restoration of hair growth [81].

\section{SENESCENT CELLS AND THEIR EFFECT ON SKIN AGING}

With age, the ability of SCs to maintain tissue homeostasis and tissue repair decreases due to several mechanisms: shortening of telomere length, reducing telomerase activity, reducing proliferative potential, weakening antioxidant protection of cells and/or increasing oxidative stress, disruption of genome DNA repair, and cells [25, 30, 70, 87]. Today the age-related decrease in the functional activity of the epidermis and hair follicle SCs is well known [26, 34, 55].

Gradually, the cells lose their functional properties; there is cellular aging - senescence. Senescent cells are located in different organs, the gradual increase in their number with age is one of the phenomena of human aging $[10,53]$. Senescent cells are not capable of replication, increase in size, are resistant to apoptosis, but retain metabolic activity [3]. In addition, they produce a number of biologically active molecules, such as proinflammatory cytokines, proteolysis factors, extracellular matrix proteases, which together form a senescence-associated secretory phenotype (SASP) $[9,22]$. The secretome of senescent cells can damage the local environment, change the functional activity of neighboring differentiated cells, stem and progenitor cells, as well as accelerate the aging of tissues [8,54].

The study of senescent dermal fibroblasts has shown an increase in the expression of the senescence-related marker p16INK4A (a protein in- volved in the mechanisms of cell division encoded by the CDKN2A gene) in vitro [15]. Later, Ressler et al. have shown that there is an increase in p16INK4A protein gene expression in dermal fibroblasts and skin epidermis of the elderly compared to the younger group of people. The p16INK4A protein directly correlates with the chronological aging of human skin, and, therefore, may be a biomarker for assessing human aging [60].

In an in vitro study, senescent fibroblasts have a reduced ability to activate in response to the impact of transforming growth factor $b-1$, which can lead to impaired collagen synthesis and wound healing [29, 67]

Analyzing the telomere dysfunction as a biomarker of aging, Herbig et al. proved that the number of senescent fibroblasts in the skin of old baboons increases exponentially, reaching the level of $15-20 \%$ of all cells [39].

According to the results of immunohistochemical study Victorelli et al., there is an increase in the number of melanocytes expressing p16INK4A in the skin of the elderly in vivo. Senescent melanocytes also have reduced expressions of the cytokine mediator high-mobility group protein B1 (HMGB1), sirtuin 1 (SIRT1) and dysfunctional telomeres, but without their shortening. Melanocyte SASP reduces the proliferation of surrounding cells by increasing the production of mitochondrial active oxygen species. Finally, older melanocytes impair basal keratinocyte proliferation and contribute to epidermal atrophy in vitro [84].

The study of Victorelli et al. proved an increase in the number of C-X-C chemokine receptor type 3 (CXCR3) for human interferon-inducible protein 10 (IP-10). IP-10 is secreted by macrophages and fibroblasts in response to interferon- $\gamma$ production. It is also expressed on the membrane of senescent melanocytes of the epidermal basal layer of the elderly skin in vitro. The addition of recombinant human IP-10 to the culture of dermal fibroblasts has led to the increased production of mitochondrial reactive oxygen species, which disrupt the function of telomeres.

The addition of the conditioned medium of senescent melanocytes to the culture of dermal fibroblasts caused telomere dysfunction on the $2^{\text {nd }}$ and $30^{\text {rd }}$ days of the study. In addition, dermal fibroblasts increased the production of the cyclin-dependent kinase p16 inhibitor, which is expressed in senescent cells, and the senescence-associated $\beta$-galactosidase (Sen- $\beta$-Gal). Both markers are considered biomarkers of aging [84].

Another experiment used an in vitro model of the epidermal equivalent consisting of proliferating or senescent melanocytes and young keratinocytes cultured in a ratio of 1:10, which during 10 days formed a multilayered highly differentiated equivalent of the epidermis. The reduce in the number of senescent melanocytes by adding the ABT-737 inhibitor molecule of the BCL-2 family of antiapoptotic proteins to such an epidermal equivalent resulted in a decrease in the percentage of p16-positive keratinocytes, which was compared with the relative content of p16-positive keratinocytes of melanoderma with young melanocytes. The obtained data testify that SASP factors of senescent melanocytes can cause telomere dysfunction by paracrine way and impair proliferation of surrounding cells accelerating the aging of neighboring epidermal cells [84].

\section{MORPHOHISTOLOGICAL AGE-RELATED CHANGES IN THE SKIN}

One of the key factors of morphological changes in the epidermis and dermis during chronological aging is decrease of cellular regeneration. There is an imbalance between cell division and differentiation as well as their death. With age, the proliferative potential of keratinocytes of the epidermis decreases, resulting in the thinning of the epidermis, as well as the number and functional activity of melanocytes [27, 65, 74, 77]. The density of antigen-presenting Langerhans cells decreases in the skin, the ability to migrate in them is significantly reduced $[71,74]$. The number of T-lymphocytes also decreases and they become less sensitive to specific antigens [50]. The epidermal-dermal junction of old skin becomes $35 \%$ thinner than the epidermal-dermal junction of young skin [62].

In the dermis, the number and functional activity of cells, collagen and elastin fibers, skin appendages change. The main cellular population of skin - fibroblasts - decreases, their biosynthetic functions also change 
[4]. Mature fibroblasts gradually turn into fibrocytes. Compared with fibroblasts, fibrocytes produce much less mucopolysaccharides, collagen, elastin, and the dermis becomes atrophic [11, 28]. According to Varani et al., the number of skin fibroblasts at the age of 80 years is reduced by $35 \%$ compared to the skin at the age of 30 years, and the ability to produce collagen is reduced by an average of $75 \%$ [83].

At a young age (20-30 years), collagen fibers are tightly packed, well organized. At the age of 80 , they become fragmented, their orderly orientation, characteristic of young skin, disappears [62]. This is due to the increased activity of zinc-dependent matrix metalloproteinases (MMPs), which destroy collagen and elastin molecules. The studies of Baroni et al. demonstrate that in women 's skin there is a decrease in the percentage of collagen type 1 and 3 , its fragmentation and disorganization, especially after the age of 60 [17].

Age-related hair changes affect the color and number of hair follicles. According to Giacometti et al., there is a decrease in the number of hair follicles on the scalp on average from 615 per $1 \mathrm{~cm}^{2}$ at the age of 20-30 to 435 per $1 \mathrm{~cm}^{2}$ at the age of $80-90$ [28]. The hair becomes thin, loses its color. By the age of 60 , approximately $50 \%$ of the population has half gray hair on the body and a higher percentage of gray/white hair on the head. The change of the color to gray is explained by a gradual decrease in the number and function of melanocytes located both in the area of hair follicles and external root sheath [23].

It is known that significant changes during aging occur in capillaries and small blood vessels. Capillaroscopy and native microscopy revealed a decrease in the number of vertical capillary loops in the papillary layer of the dermis, as well as a decrease in vascular density per area [86]. The functional activity of both mature and stem cells of the skin is impaired, gradually increasing atrophic and dystrophic changes in all its structures $[1,61]$

\section{DERIMATOPOROSIS - A SYNDROME OF SKIN AGING}

Skin aging has long been seen largely as an aesthetic problem. The correction of age-related skin changes was carried out mainly with the help of cosmetics. As life expectancy increases, we begin to experience skin changes that progress with age and become not only cosmetic but also functional - the skin gradually loses its functions (protective, barrier and others). Therefore, in order to study the chronic changes that occur during aging and are accompanied by the development of chronic skin insufficiency syndrome, as well as the development of means to restore skin function in elderly patients, scientists have proposed the term dermatoporosis [46].

According to the etiological classification, there are:

- $\quad$ primary dermatoporosis, which is the most common and occurs due to chronological aging and long-term exposure to sunlight in unprotected areas.

- secondary iatrogenic dermatoporosis, which occurs during long-term intake of systemic and/or local corticosteroids for the treatment of various diseases $[12,46]$.

Among main diagnoses used to describe the clinical picture of aging of the face and skin, ICD-10 distinguishes two nosologies associated with age-related skin changes: chronoaging - "senile skin atrophy" (code $L 57.4$ ) and photoaging - "skin changes due to chronic exposure to nonionizing radiation" (code L 57).

The first signs of dermatoporosis appear around the age of 60 , but the disease develops between the ages of 70 and 90 . The clinical manifestations of both types do not differ from each other, but iatrogenic dermatoporosis may occur earlier and be more severe in patients susceptible to primary dermatoporosis.

Manifestations of dermatoporosis are divided into:

- $\quad$ clinical - skin atrophy, senile purpura, stellate pseudoscars, trophic ulcers;

- functional - reduced wound healing, damage/frequent ruptures of the skin from minor injuries, non-healing of atrophic ulcers and subcutaneous bleeding with the formation of hematomas, leading to necrosis $[46,72]$.
In its turn, the clinical signs of atrophic process at the level of the epidermis and dermis of human skin are manifested by the appearance of superficial and deep wrinkles, as well as pigmented spots, the formation of gravitational ptosis, decreased sebum and sweat production, the development of dry skin [27, 28].

CD44 expression and hyaluronic acid levels are reduced in the epidermis and dermis of patients with dermatoporosis compared to the skin of young people, therefore, some researchers consider this fact as one of the potential molecular mechanisms of involutive skin changes and the clinical picture of dermatoporosis [45]. According to Kaya G. et al., the regulation of keratinocyte proliferation in response to extracellular stimuli and maintenance of local homeostasis have been shown to be key functions of CD44 in mouse skin [43]. Keratinocytes with the loss of CD44 expression have a defect in their ability to proliferate in response to various stimuli, which is accompanied by the development of the atrophy of mice epidermis both in vivo and in vitro $[43,45]$.

\section{MODERN APPROACHES IN THE TREATMIENT OF SKIN AGING}

For the treatment of age-related skin changes, there are used:

- $\quad$ cosmetics and daily skin care (creams, masks, sunscreens);

- $\quad$ topical pharmacotherapeutic agents (retinoids, antioxidants);

- invasive procedures (biorevitalization, mesotherapy, chemical peelings);

- hardware techniques (laser therapy, Intense Pulse Light therapy - IPL, Radio Frequency Lifting - RF therapy);

- $\quad$ systemic therapy (hormone replacement therapy, antioxidants);

- $\quad$ regenerative cell technologies: platelet-rich plasma (PRP therapy), stem cells.

In addition, it is extremely important to avoid bad habits (smoking and alcohol consumption), stress control, providing the necessary nutrients, adequate sleep and exercise, dietary and caloric restrictions $[33,56]$.

Retinoids and their derivatives are widely used in the complex treatment of involutive skin changes. According to Kaya G. et al., topical application of retinaldehyde increases the expression of CD44 and hyaluronic acid synthase in the skin of mice [44]. Topical application of retinaldehyde and hyaluronic acid increased the level of these molecules in the skin of patients with dermatoporosis and corrected skin atrophy, demonstrating a synergistic effect at both molecular and clinical levels [46]. Vitamin A (retinol) and its derivatives (retinaldehyde and tretinoin) have an antioxidant effect, can induce collagen biosynthesis and reduce the expression of MMP-1 [42]. Tretinoin is a non-aromatic first-generation retinoid approved in the United States for use as an anti-aging agent [66].

Involutive skin changes are very closely related to stem cell function, so the use of these cells in anti-aging strategies, as well as the treatment of patients with stem cells or their differentiated derivatives can be a universal technique in regenerative and aesthetic medicine [24, 70]. Subcutaneous adipose tissue is the most available source of mesenchymal stem cells isolation for transplantation. In dermatology and aesthetic medicine today, lipoaspirate, stromal-vascular fraction and cultured adipose tissue stem cells are widely used to correct age-related skin changes.

For example, according to Park B. et al., the administration of lipoaspirate intradermally into the skin of patients with the signs of photoaging led to a decrease in wrinkle depth, significant improvement in skin texture, increase in dermis thickness, as evidenced by ultrasonography, two months after the last injection [57]. In the study of Amirkhani et al., subcutaneous administration of adipose-derived stem cells in the nasolabial folds 6 months after the injection shows an increase in the density of the dermis, its thickness, a decrease in transepidermal water loss [16]. The injection of autologous fat enriched with stromal-vascular fraction in patients diagnosed with androgenic alopecia showed a doubling of hair growth density compared with the patients who received only injections of their autologous fat without SVF [58]. 126 patients participated in the study of rejuvenating and volumizing effects of stromal-vascular gel (SVF-gel). All participants noted an improvement in facial contours, reduction of wrinkles [82]. 
However, the clinical application of stem cells has a number of limitations: they are contraindicated in pregnancy, cancer, HIV/AIDS. Stem cell treatment is more costly and time consuming than the use of pharmaceuticals, as they require special reagents and equipment to isolate, grow, control the quality of cells and their subsequent transplantation. The use of allogeneic cells requires some caution about the risk of infection transmission. In the case of the latest autologous induced pluripotent cell (iPSC) technology, there are some safety concerns due to their ability to provoke the development of teratomas [13].

Given the above, we can assume that the microenvironment will be the next promising therapeutic strategy to influence age-related skin changes. However, the current state of research demonstrates the inability to reliable and long-term recovery of tissue microenvironment, which will contribute to the normalization of the functional activity of stem cells and surrounding cells, resulting in a decrease in the level of senescent cells [69]. Under these conditions, there are prospective means that improve the tissue microenvironment of cells, which will restore the functional activity of cells.

One of the means of therapeutic strategy aimed at the treatment of age-related diseases and skin rejuvenation is the widespread use of senotherapy in the treatment of cellular aging. They are divided into:

- $\quad$ senolytics - drugs that reduce the number of senescent cells;

- $\quad$ senomorphics - drugs that reduce the secretion of SASP-associated cytokines;

- geroprotectors - means to prevent aging, which reduce the manifestations of oxidative stress and telomere damage [51].

For example, according to Zhu et al., the combination of the proapoptotic drug dasatinib and the bioflavonoid quercetin significantly reduced the number of senescent C12FDG-positive primary mouse embryonic fibroblasts compared to these drugs alone [76]. According to Hickson et al., the treatment with the combination of dasatinib and quercetin in patients with diabetic nephropathy caused a decrease in epidermal cells expressing p16ink4A and p21CIPI, circulating SASP factors, including IL-1a, IL-6, MMPs-9 and MMPs-12, and senescent-dependent adipocytes protein inhibitor ( $\mathrm{p} 16$ ink4A) and cyclin-dependent kinase inhibitor 1 (p21CIP1) [40].

Another well-known drug is resveratrol (3,4,5-trihydroxystilbene, RSV), a natural polyphenolic compound with antioxidant properties found in red grapes, berries and some vegetables. Multiple protective effects on the human body (lowering glucose levels, improving insulin sensitivity, lowering the level of C-reactive protein, triglycerides) allow us to consider resveratrol as a means of slowing down the aging process of the body and skin in particular [85]. Resveratrol as a geroprotector is increasingly used in clinical practice and demonstrates a reduction in clinical markers of aging in human skin at systemic use. The intake of $8 \mathrm{mg}$ of resveratrol for 60 days in the study group resulted in improved skin hydration and elasticity, reduced wrinkle depth, roughness and pigment spot intensity compared with the placebo control group [21]. According to histological examination, the addition of resveratrol gel to the skin of rats after pre-surface peeling for 15 days caused the thickening of the epidermis and dermis [37].

The first clinical and experimental data on the use of senotherapy allow us to consider them as a new anti-aging strategy. However, the widespread application of senotherapy in clinical practice requires additional study of a number of issues:

- the interaction of senotherapeutics with each other and with medicines as well as with non-drug treatments;

- $\quad$ the identification of side effects;

- doses, schemes, the duration of treatment for various diseases;

- the rate of accumulation of aging cells after their removal in different diseases, in different tissues and at different ages [49].

\section{CONCLUSION}

The microenvironment affects the functional activity of human skin stem cells. The functional activity of old stem cells can be restored, which provides new promising ways for regenerative and aesthetic dermatology.

Research is needed to identify and correct a key microenvironmental factor that negatively affects stem cell functions, and to develop effective therapeutic strategies to preserve skin function and restore it in old age. The latest data contribute to the further development of geriatric dermatology and better treatment of age-associated skin diseases.

\section{REFERENCES:}

1. Araviyskaya $E R$. Vozrastnye izmeneniya v derme: novye svedeniya i puti korrektsii s pomoshch'yu sredstv dlya ezhednevnogo ukhoda [Age-related changes in the dermis: new information and ways of correction with the help of means for daily care]. Russkiy meditsinskiy zhurnal - Russian medical journal. 2008; 8:574-575. [In Russian]

2. Volkova NA, Mazur SP, Kholodny VS, Petrenko AYu. Stvolovye kletki kozhi kak ob»ekt kriokonservirovaniya [Skin stem cells as an object of cryopreservation]. Problemy kriobiologii i kriomeditsiny - Problems of cryobiology and cryomedicine. 2014; 24(1):3-15. [In Russian]

3. Dudinskaya EN, Tkacheva ON, Machekhina LV, Kotovskaya YuV, Leontyeva IV, Kovalev IA, et al. Rol' insulinorezistentnosti i arterial'noy gipertonii v protsessakh replikativnogo kletochnogo stareniya [The role of insulin resistance and arterial hypertension in the processes of replicative cellular aging]. Arterial'naya gipertenziya - Arterial hypertension. 2019; 25(3):225-231. [In Russian]

4. Zorina A. Fibroblasty kozhi i effektivnost' anti - eydzh korrektsii [Skin fibroblasts and the effectiveness of anti-age correction]. Kosmetik international. 2013; 2:1423. [In Russian]

5. Kalyuzhnaya $L D$. Starenie kozhi i khronicheskie dermatozy u zhenshchin menopauzal'nogo perioda [Skin aging and chronic dermatoses in menopausal women]. 2006. Available from: https://mazg.com.ua/ru-issue-article-10. [In Russian]

6. Kamalov AA, Okhobotov DA. Stvolovye kletki i ikh ispol'zovanie v sovremennoy klinicheskoy praktike [Stem cells and their use in modern clinical practice]. Urologiya - Urology. 2012; 5:105-114. [In Russian]

7. Kishkun AA. Biologicheskiy vozrast i starenie: vozmozhnosti opredeleniya i puti korrektsii. [Biological age and aging: possibilities of definition]. Ruk-vo dlya vrachey - Manual for doctors. Moskva: GEOTAR-Media, 2008. 973 p. [In Russian]

8. Malygina NA. Starenie kletok i vozrastzavisimye zabolevaniya [Cell aging and age-related diseases]. Klinicheskaya gerontologiya - Clinical gerontology. 2014; 3-4:30-34. [In Russian]

9. Moskalev AA. Rol' stvolovoy nishi v protsessakh stareniya organizma [The role of the stem niche in the aging process of the body]. Ros Khim Zhurnal - Rus Chem J. 2009; 53(3):83-87. [In Russian] 
10. Paltsyn AA. Senolitiki. Patogenez [Senolytics. Pathogenesis]. 2019; 17(4):78-84. [In Russian]

11. Ruksha TG, Aksenenko MB, Klimina GM, Novikova LV. Vnekletochnyy matriks kozhi: rol' v razvitii dermatologicheskikh zabolevaniy [Extracellular matrix of the skin: role in the development of dermatological diseases]. Vestnik dermatologii i venerologii - Bulletin of Dermatology and Venereology. 2013; 6:32-39. [In Russian]

12. Shirshakova M. Klinicheskaya effektivnost' stimulyatsii kozhi preparatami nativnoy gialuronovoy kisloty v zerkale instrumentel'noy diagnostiki [Clinical efficacy of skin stimulation with preparations of native hyaluronic acid in the mirror of instrumental diagnostics]. In»ektsionnye metody v kosmetologii - Injection methods in cosmetology. 2010; 3:74-81. [In Russian]

13. Abad M, Mosteiro L, Pantoja C, Cañamero M, Rayon T, Ors I, et al. Reprogramming in vivo produces teratomas and iPS cells with totipotency features. Nature. 2013; 502(7471):340-5.

14. Ali N, Zirak B, Rodriguez RS, Pauli ML, Truong HA, Lai K, et al. Regulatory T Cells in Skin Facilitate Epithelial Stem Cell Differentiation. Cell. 2017; 169(6):11191129.

15. Alcorta DA, Xiong Y, Phelps D, Hannon G, Beach D, Barrett JC. Involvement of the cyclin-dependent kinase inhibitor p16 (INK4a) in replicative senescence of normal human fibroblasts. PNUS USA. 1996; 93(24):13742-13747.

16. Amirkhani MA, Shoae-Hassani A, Soleimani M, Hejazi S, Ghalichi L, Nilforoushzadeh MA. Rejuvenation of facial skin and improvement in the dermal architecture by transplantation of autologous stromal vascular fraction: a clinical study. Bioimpacts. 2016; 6(3):149-154.

17. Baroni Edo R, Biondo-Simões Mde L, Auersvald A, Auersvald LA, Montemor Netto MR, Ortolan MC, et al. Influence of aging on the quality of the skin of white women: the role of collagen. Acta Cir Bras. 2012; 27(10):736-40.

18. Beausejour CM, Campisi J. Balancing regeneration and cancer. Nature. 2006; 443(7110):404-405.

19. Blanpain C, Fuchs E. Epidermal stem cells of the skin. Annu Rev Cell Dev Biol. 2006; 22:33-373.

20. Blanpain C, Fuchs E. Epidermal homeostasis: a balancing act of stem cells in the skin. Nat Rev Mol Cell Biol. 2009; 10(3):207-17.

21. Buonocore D, Lazzeretti A, Tocabens P, Nobile V, Cestone E, Santin G, et al. Resveratrol-procyanidin blend: nutraceutical and antiaging efficacy evaluated in a placebocontrolled, double-blind study. Clin Cosmet Investig Dermatol. 2012; 5:159-65.

22. Campisi J. Senescent Cells, Tumor Suppression, and Organismal Aging: Good Citizens, Bad Neighbors. Cell. 2005; 120(4):513-522.

23. Commo $S$, Gaillard 0 , Bernard BA. Human hair greying is linked to a specific depletion of hair follicle melanocytes affecting both the bulb and the outer root sheath. Br Journal of Dermatology. 2004; 150(3):435-43.

24. Daley GQ. The promise and perils of stem cell therapeutics. Cell Stem Cell. 2012; 10:740-749.

25. Dasgupta J, Kar S, Liu R, Joseph J, Kalyanaraman B, Remington SJ, et al. Reactive oxygen species control senescence-associated matrix metalloproteinase-1 through C-Jun-N-terminal kinase. J Cell Physiol. 2010; 225(1):52-62.

26. Doles J, Storer M, Cozzuto L, Roma G, Keyes WM. Age-associated inflammation inhibits epidermal stem cell function. Genes Dev. 2012; 26(19):2144-2153.

27. Farage AM, Miller WK, Maibach IH. Textbook of Aging Skin. Springer. 2017. 2222 p.

28. Fenske NA, Lober CW. Structural and functional changes of normal aging skin. J Am Acad Dermat. 1986; 15(4):571-585.

29. Fisher GJ, Varani J, Voorhees JJ. Looking older: Fibroblast collapse and therapeutic implications. Arch Dermatol. 2008; 144:666e672.

30. Flores I, Blasco MA. The role of telomers and telomerase in stem cell aging. FEBS Lett. 2010; 584(17):3826-30.

31. Fuchs E. Skin stem cells: rising to the surface. J Cell Biol. 2008; 180(2):273-284.

32. Fujiwara H, Ferreira M, Donati G, Marciano DK, Linton JM, Sato Y, et al. The basement membrane of hair follicle stem cells is a muscle cell niche. Cell. 2011; 144(4):577-89.

33. Ganceviciene $R$. Skin anti-aging strategies. Dermatoendocrinol. 2012; 4(3):308-319.

34. Giangreco A, Qin M, Pintar JE, Watt FM. Epidermal stem cells are retained in vivo throughout skin aging. Aging Cell. 2008; 7:250-259.

35. Guasch G. The Epithelial Stem Cell Niche in Skin. Biology and Engineering of Stem Cell Niches. Academic Press. 2017; 127-143.

36. Chu GY, Chen YF, Chen HY, Chan MH, Gau CS, Weng SM. Stem cell therapy on skin: Mechanisms, recent advances and drug reviewing issues. J Food Drug Anal. 2018; 26(1):14-20.

37. Gonçalves GMS, Barros PP, da Silva GH, dos Santos EM, Minutti AF. Formulations containing curcumin or trans-resveratrol increase dermal thickness in rats submitted to chemical peeling. J Cosmet Dermatol Sci Appl. 2017; 7:14-26.

38. Gonzales K, Fuchs E. Skin and its regenerative powers: an alliance between stem cells and their niche. Dev Cell. 2017; 43:387-401.

39. Herbig U, Ferreira M, Condel L, Carey D, Sedivy JM. Cellular senescence in aging primates. Science. 2006; 311(5765):1257.

40. Hickson LJ, Langhi Prata LGP, Bobart SA, Evans TK, Giorgadze N, Hashmi SK, et al. Senolytics decrease senescent cells in humans: Preliminary report from a clinical trial of Dasatinib plus Quercetin in individuals with diabetic kidney disease. EBioMedicine. 2019; 47:446-456.

41. Jeong JH. Adipose stem cells and skin repair. Curr Stem Cell Res Ther. 2010; 5(2):137-40.

42. Kafi R, Kwak HS, Schumacher WE, Cho S, Hanft VN, Hamilton TA. Improvement of naturally aged skin with vitamin A (retinol). Arch Dermatol. 2007; 143:606-12.

43. Kaya G, Rodriguez I, Jorcano JL, Vassalli P. Stamenkovic I. Selective suppression of CD44 in keratinocytes of mice bearing an antisense CD44 transgene driven by a tissuespecific promoter disrupts hyaluronate metabolism in the skin and impairs keratinocyte proliferation. Genes Dev. 1997; 11:996-1007.

44. Kaya G, Grand D, Hotz R, Augsburger E, Carraux P, Didierjean L, et. al. Upregulation of CD44 and hyaluronate synthases by topical retinoids in mouse skin. J Invest Dermatol. 2005; 124:284-287.

45. Kaya G, Tran C, Sorg O, Hotz R, Grand D, Carraux P, et al. Hyaluronate fragments reverse skin atrophy by a CD44-dependent mechanism. PLoS Med. $2006 ; 3$ :e493.

46. Kaya G, Saurat JH. Dermatoporosis: a chronic cutaneous insufficiency/fragility syndrome. Dermatology 2007; 215:284-294.

47. Keyes BE, Segal JP, Heller E, Lien WH, Chang CY, Guo X. Nfatc1 orchestrates aging in hair follicle stem cells. PNUS USA. 2013; 110(51):E4950-9.

48. Khavkin J, Ellis DA. Aging skin: histology, physiology, and pathology. Facial Plast Surg Clin North Am. 2011; 19(2):229-34.

49. Kirkland JL, Tchkonia T. Cellular senescence: A translational perspective. EBioMedicine. 2017; 21:21-28.

50. Kligman AM. Perspectives and problems in cutaneous gerontology. J Invest Dermatol. 1979; 73:39-46.

51. Lagoumtzi SM, Chondrogianni N. Senolytics and senomorphics: Natural and synthetic therapeutics in the treatment of aging and chronic diseases. Free Radic Biol Med. 2021; 171:169-190.

52. Lane SW, Williams DA, Watt FM. Modulating the stem cell niche for tissue regeneration. Nat Biotechnol. 2014; 32(8):795-803.

53. Waaijer $M$, Goldeck $D$, Gunn $D A$, van Heemst $D$, Westendorp R, Pawelec G, Maier AB. Are skin senescence and immunosenescence linked within individuals? Aging cell. 2019;18(4):12956. Available from: https://doi.org/10.1111/acel.12956 
54. Nelson G, Wordsworth J, Wang C, Jurk D, Lawless C, Martin-Ruiz C, et al. A senescent cell bystander effect: senescence-induced senescence. Aging Cell. 2012; 11:345-349.

55. Matsumura $H$, Mohri $Y$, Binh NT, Morinaga $H$, Fukuda $M$, Ito $M$, et al. Hair follicle aging is driven by transepidermal elimination of stem cells via CoL17A1 proteolysis. Science. 2016; 351(6273):aad4395.

56. Mohiuddin AK. Skin Aging \& Modern Age Anti-aging Strategies. GJMR: B Pharma, Drug Discovery, Toxicology \& Medicine. 2019; 19 (2). Version 1.0.

57. Park BS, Jang AK, Sung HJ, Park SJ, Kwon HY. Adipose-Derived Stem Cells and their secretory factors as a promising therapy for skin aging. Dermatol Surg. 2008; 34:1323-1326.

58. Perez-Meza D, ZieringC, Sforza M, Krishnan G, Ball E, Daniels $E$. Hair follicle growth by stromal vascular fraction-enhanced adipose transplantation in baldness. Stem Cells Cloning. 2017; 10:1-10.

59. Rando TA. Stem cells, ageing and the quest for immortality. Nature. 2006; 41(7097):1080-1086.

60. Ressler S, Bartkova J, Niederegger H, Bartek J, Scharffetter-Kochanek K, Jansen-Durr $P$, et al. p16INK4A is a robust in vivo biomarker of cellular aging in human skin. Aging Cell. 2006; 5:379-389.

61. Rittié L, Fisher G. Natural and sun-induced aging of human skin. Cold Spring Harb Perspect Med. 2015; 5(1):1-14.

62. Quan T, Fisher GJ. Role of Age-Associated Alterations of the Dermal Extracellular Matrix Microenvironment in Human Skin Aging: A Mini-Review. Gerontology. 2015; 61(5):427-34.

63. Quan T. Molecular mechanisms of skin aging and age-related diseases. CRC Press. 2016. 326 p.

64. Schofield $R$. The relationship between the spleen colony-forming cell and the haemopoietic stem cell. Blood Cells. 1978; 4(1-2):7-25.

65. Seyfarth F, Schliemann S, Antonov D, Elsner P. Dry skin, barrier function, and irritant contact dermatitis in the elderly. Clin Dermatol. 2011; 29(1):31-36.

66. Mane S, Vinchurkar K, Khan M, Sainy J, Nirmal S, Singh R, et al. Skin Anti-Ageing Strategies: A Review. Int J Eng Technol. 2019 ; 4(7):255-263.

67. Simpson RM, Wells $A$, Thomas $D$, Stephens $P$, Steadman $R$, Phillips A. Aging fibroblasts resist phenotypic maturation because of impaired hyaluronan-dependent CD44/epidermal growth factor receptor signaling. Am J Pathol. 2010; 176(3):1215-1228.

68. Smith L. Histopathologic characteristics and ultrastructure of aging skin. Cutis. 1989; 43(5):414-24.

69. Strnadova K, Sandera V, Dvorankova B, Kodet O, Duskova M, Smetana K, et. al. Skin aging: the dermal perspective. Clinics in Dermatology. 2019; 37(4):326-335.

70. Taub AF, Pham K. Stem Cells in Dermatology and Anti-aging Care of the Skin. Facial Plast Surg Clin North Am. 2018; 26(4):425-437.

71. Thiers BH, Maize JC, Spicer SS, Cantor AB. The effect of aging and chronic sun exposure on human Langerhans cell populations. J Invest Dermatol. 1984; 82(3):223-226.

72. Thompson MW, Aitken DA, van der Mei IA, Otahal P, Cicolini J, Winzenberg TM, et al. Predictors of Beagley-Gibson skin cast grade in older adults. Skin Res Technol. 2017; 23:235-242.

73. Toma JG, McKenzie IA, Bagli D, Miller FD. Isolation and characterization of multipotent skin-derived precursors from human skin. Stem Cells. 2005; 23(6):727-37.

74. Tobin DJ. Introduction to skin aging. Journal of Tissue Viability. 2017; 26(1):37-44.

75. Zaki SM. Characteristics of the Skin of the Female Albino Rats in Different Ages: Histological, Morphometric and Electron Microscopic Study. J Cytol Histol. 2015; 3:004.

76. Zhu Y, Tchkonia T, Pirtskhalava T, Gower AC, Ding H, Giorgadze N, et al. The achilles' heel of senescent cells: From transcriptome to senolytic drugs. Aging cell. 2015; 14(4):644-658.

77. Zouboulis CC, Makrantonaki E. Clinical aspects and molecular diagnostics of skin aging. Clin Dermatol. 2011; 29(1):3-14.

78. Uitto J. The Role of elastin and collagen in cutaneous aging: intristic aging versus photoexposure. Journal of drug in dermatology. $2008 ; \mathbf{8 ( 2 ) : ~} 12-16$.

79. Yamanishi H, Fujiwara S, Soma T. Perivascular localization of dermal stem cells in human scalp. Exp Dermatol. 2012; 21(1):78-80.

80. Yang L, Peng R. Unveiling hair follicle stem cells. Stem Cell Reviews and Reports. 2010; 6(4): 658-664.

81. Ge Y, Miao Y, Gur-Cohen S, Gomez N, Yang H, Nikolova M, et al. The aging skin microenvironment dictates stem cell behavior. PNUS USA. 2020; 117(10):53395350.

82. Yao Y, Cai J, Zhang P, Liao Y, Yuan Y, Dong Z, et al. Adipose Stromal Vascular Fraction Gel Grafting: A New Method for Tissue Volumization and Rejuvenation. Dermatol Surg. 2018; 44(10):1278-1286.

83. Varani J, Dame M, Rittie L, Fligiel S.E, Kang S, Fisher GJ, et al. Decreased collagen production in chronologically aged skin. Roles of age-dependent alteration in fibroblast function and defective mechanical stimulation. Am J Pathol. 2006; 168(6):1861-1868.

84. Victorelli $S$, Lagnado A, Halim J, Moore W, Talbot D, Barrett $K$, et al. Senescent human melanocytes drive skin ageing via paracrine telomere dysfunction. EMBO J. 2019; 38(23):e101982.

85. Wahab A, Gao K, Jia C, Zhang F, Tian G, Murtaza G, et al. Significance of Resveratrol in Clinical Management of Chronic Diseases. Molecules. 2017 ; 22(8):1329.

86. Waller JM, Maibach HI. Age and skin structure and function, a quantitative approach (I): blood flow, pH, thickness, and ultrasound echogenicity. Skin Res Technol. 2005; 11(4):221-35.

87. Wang C, Jurk D, Maddick M, Nelson G, Martin-Ruiz C, von Zglinicki T. DNA damage response and cellular senescence in tissues of aging mice. Aging Cell. 2009; $\mathbf{8}(3): 311-23$.

88. Wong VW, LeviB, Rajadas J, LongakerMT, Gurtner GC. Stem cell niches for skin regeneration. Int J Biomat. 2012. Available from: https://doi.org/10.1155/2012/926059

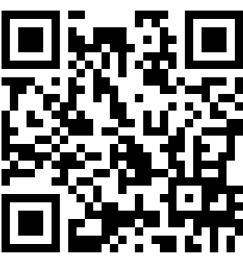

ARTICLE ON THE SITE

TRANSPLANTOLOGY.ORG
The authors declared no potential conflicts of interest with respect to the research, authorship, and/or publication of this article. 
УДК 611.77:612.67

\section{Сучасні уявлення про старіння шкіри та способи його корекції}

(ब) Іваніщев В. М.

Державна установа «Інститут геронтології ім. Д. Ф. Чеботарьова Національної академії

медичних наук України», Київ, Україна

\section{PEЗЮME}

У статті проаналізовані сучасні експериментальні та клінічні дані щодо старіння шкіри. Один із френоменів старіння шкіри - це старіння ії клітин. Сенесцентні клітини продукують спектр цитокінів, що змінюють мікрооточення тканин. Результати останніх досліджень показують, що мікрооточення впливає на функціональну активність стовбурових клітин шкіри, що супроводжується погіршенням їі регенерації та відновлення.

кЛючовІ словА: старіння шкіри; стовбурові клітини шкіри; сенесцентні клітини; сенолітики 